\title{
PERANCANGAN APLIKASI GO GROUPH MATH SEBAGAI SARANA PENYELESAIAN TUGAS KELOMPOK
}

\author{
Shinta Dwi Handayani ${ }^{1}$, Aulia Paramita ${ }^{2}$, Alusyanti Primawati ${ }^{3}$ \\ Program Studi Informatika, Universitas Indraprasta PGRI ${ }^{1,2,3}$ \\ Email: shintadh.1109@gmail.com ${ }^{1}$
}

\begin{abstract}
Abstrak
Tujuan dari penelitian ini adalah untuk merancang groupware berbasis android yang dinamakan Go Group Math sebagai bagian dari media atau aplikasi pendukung kerja kelompok khususnya yang nanti akan dapat digunakan untuk mata pelajaran matematika. Metode yang digunakan dalam penelitian ini adalah Research and Development (RnD) dengan menggunakan model ADDIE yaitu Analyze, Design, Development, Implementation, dan Evalation. Kegiatan dalam penelitian yang dilakukan pada riset ini baru sampai pada tahapan melakukan perancangan tampilan layar yang akan digunakan nantinya pada tahap pengembangan aplikasi dengan menggunakan berbagai sumber basis data. Hasil penelitian ini adalah sudah terdapat tampilan desain layar yang nantinya akan digunakan sebagai tampilan layar pada ponsel pintar android. Penelitian ini diharapkan dapat bermanfaat bagi berbagai kalangan dalam dunia pendidikan khusunya guru, dosen, siswa dan mahasiswa.

Kata kunci: Go Grouph Math, Apikasi Pembelajaran Kelomopok, Aplikasi Android, Pendidikan Matematika

Abstract

The purpose of this research is to design an android-based groupware called Go Group Math as part of the media or application to support group work in particular which can later be used for mathematics subjects. The method used in this research was Research and Development (RnD) using the ADDIE model, namely Analyze, Design, Development, Implementation, and Evaluation. Activities in research carried out in this research have only reached the stage of designing a screen display that will be used later in the application development stage using various database sources. The results of this study discovered that there was already a display screen design that will be used as a screen display on an Android smartphone. This research was expected to be useful for various groups in the world of education, especially teachers, lecturers, students, and students.
\end{abstract}

Keywords: Go Grouph Math, Group Learning Application, Android Application, Mathematics Education

\section{PENDAHULUAN}

Seiring dengan perkembangan teknologi infomasi dan komunikasi maka perlu adanya aplikasi yang dapat menunjang kegiatan pembelajaran sehingga pembelajaran dapat efektif dan efiesien. Keadaan saat ini efek pandemic covid-19 perlu adanya strategi dalam melakukan kegiatan pembelajaran yang dilakukan secara daring. mahasiswa perlu adanya aplikasi yang dapat membantu dengan mudah kegiatan pembelajaran yang dilakukan di rumah.

Saat ini memang sudah banyak aplikasi groupware yang ada untuk menunjang kegiatan pemnbelajaran daring khusunya ketika tugas-tugas yang diberikan memerlukan kerja kelompok. Salah satu aplikasi groupware yaitu dropbox, namun aplikasi ini harus berlanganan ketika memerlukan kapasitas penyimpaan yang besar dan ini masih umum untuk semua kalangan.

Kemajuan teknologi yang sangat pesat bisa sangat membantu dalam meningkatkan kualitas pendidikan di suatu negara pada umumnya dan daerah pada khususnya. Kemahiran menggunakan teknologi telah menjadi suatu hal yang "wajib" dimiliki oleh lulusan perguruan tinggi untuk terjun 
di dunia kerja [1]. Berbagai macam media banyak digunakan oleh pendidik untuk memudahkan dalam proses belajar mengajar dikelas [2]. Media bisa meningkatkan dan mengarahkan perhatian peserta didik sehingga bisa menimbulkan motivasi belajar, interaksi yang lebih langsung antara siswa dan lingkungannya serta kemampuan siswa untuk belajar sendiri sesuai dengan kemampuannya [3]. Pengembangan media pembelajaran dengan memanfaatkan telepon seluler adalah dengan membuat mobile learning yang ditujukan untuk semua telepon seluler berplatform Android [4].

Aplikasi groupware yang akan dibuat oleh peneliti yaitu aplikasi yang nantinya dikhusunkan untuk dapat digunakan oleh pendidikan dan peserta didik. Diharapkan dengan adanya aplikasi ini dapat membantu siswa dan guru dalam berkoordinasi mengenai tugas-tugas yang diberikan. Guru dapat memantau perkemabangan tugas siswa, siswa juga dapat mengumpulkan tugas secara teratur dan mudah dengan adanya aplikasi ini. Aplikasi ini akan diberi nama Go Grouph Math dimana aplikasi ini digunakan sebagai penunjang media pembelajaran matematika khusunya walau tidak menutup kemungkinan aplikasi ini dapat digunakan sebagai penunjang mata pelajaran lainnya.

Keunggulan dari aplikasi yang dibuat ini adalah siswa dapat membentuk kelompok belajar sehingga dapat membantu siswa yang kurang paham atas penyampaian materi yang disajikan oleh pengajar sehingga dapat belajar dengan teman sekelompoknya dan diharapkan ini dapat meningkatkan hasil belajar siswa. Maka dari itu atas pertimbangan demikian penelti melakukan perancangan aplikasi penunjang pembelajaran matematiika Go Group Math.

\section{METODE}

Metode yang digunakan dalam penelitian ini adalah Reseach and Development (RnD) dengan menggunakan model ADDIE. Yaitu tahapan analyze, design, development, implementation, dan evaluation. Kegiatan penelitian yang dilakukan baru pada sampau tahan desain tampilan layer yang nantinya akan di kembangkan untuk menajadi sebuah aplikasi pembelajaran matematika bernama Go Grouph Math khusus untuk pembelajaran matematika. Teknik analisis data yang digunakan dalam penelitian dan pengembangan yaitu, deskriptif kuantitatif untuk mengolah data dalam bentuk skor dari penilaian oleh validator dan respon siswa, sedangkan deskriptif kualitatif untuk mendeskripsikan data berupa komentar saran perbaikan dari validator [5].

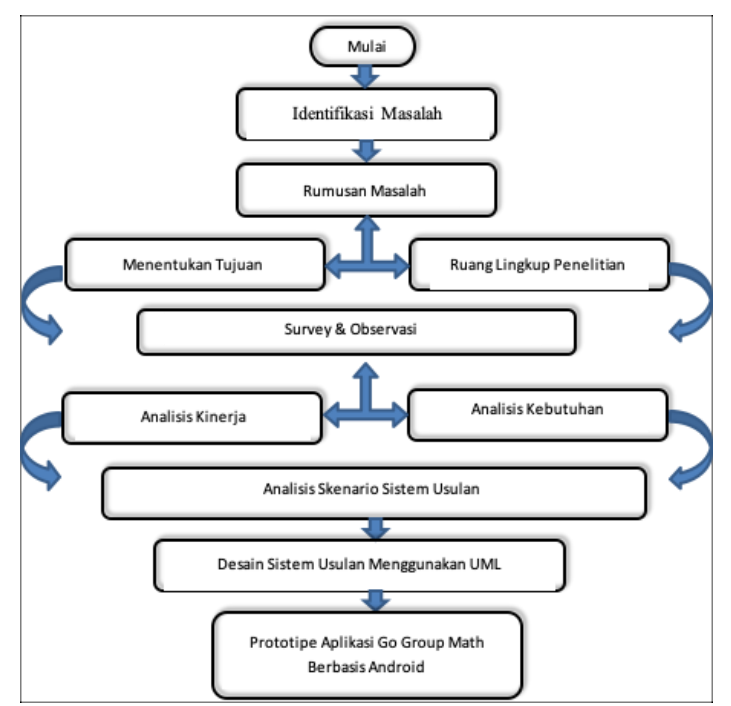

Gambar 1: Bagan Alir Kegiatan Penelitian yang dilakukan

\section{HASIL DAN PEMBAHASAN}

Tahapan penelitian yang dilakukan pertama-tama adalah analisis. Peneliti melakukan analisis kebutuhan terkakit media yang diperlukan untuk melakukan kegiatan pembelajaran khusunya pembelajaran mata kuliah logka matematikayang yang diajarkan pada semsester genap tahun akadmik 2019/2020. 


\section{Analisis kebutuhan}

Peneliti melakukan analisis awal bagaimana proses kegiatan pembelajaran mata mata kuliah logika matematika dilakukan dikelas. Pengelolaan tugas-tugas yang diberikan dosen menjadi bagian penting untuk dibuat menjadi lebih rapih mengingat dalam satu mata kuliah seorang dosen mengajar beberapa kelas. Meminamlisir kesalahan dalam meberikan penilan tugas maka seorang dosen perlu adanya aplikasi yang dapat membantu unuk meringankan tugasnya, selain itu aplikasi yang akan didesain ini akan mempermudah mahasiswa dalam mengumpulkan dna memantau tugas-tugas yang diberikan sehingga akan dapat dengan mudah dipahami dan dimengerti oleh dosen apakah mahasiswa sudah mengumpulkan tugas kelompoknya atau belum.

Langkah-langkah

pengembangan

sistemnya yaitu 1) User melakukan registrasi ke sistem Go Group Math sebagai dosen dengan memasukkan data berupa: NIDN untuk dosen dan NUPTK untuk guru, email, nama lengkap dan password. 2) Setelah user melakukan registrasi, maka sistem akan melakukan verifikasi data registrasi user sebagai dosen dengan mengirimkan email aktivasi. 3) Dosen dapat masuk ke sistem dengan login terlebih dahulu, setelah itu dapat melihat ataupun merubah profil. 4) User yang terdaftar sebagai dosen memiliki hak akses untuk dapat mengunggah materi dan tugas ke dalam sistem Go Group Math. 5) Proses unggah materi dan tugas, yaitu dosen memasukkan data mata kuliah dan pertemuan, kemudian mulai unggah materi dan lanjut ke proses berikutnya yaitu tambah tugas. 6) Langkah berikutnya saat dosen mulai menambahkan tugas maka sistem akan membuat kode tugas secara otomatis lalu dosen memasukkan jenis soal, jumlah soal, no soal, poin dan pertanyaan.
Setelah data diisi maka tugas dapat dikirim lalu dosen dapat melanjutkan untuk soal nomor yang berikutnya. 7) User berikutnya yang dapat mendaftar ke sistem yaitu sebagai mahasiswa dengan melakukan registrasi dan memasukkan data berupa: NPM, email, nama lengkap, kelas dan password. 8) Setelah mahasiswa melakukan registrasi maka sistem akan melakukan verifikasi data dengan mengirimkan email aktivasi. 9) Mahasiswa dapat melihat dan merubah profil dengan melakukan login terlebih dahulu ke dalam sistem. 10) Mahasiswa yang telah terdaftar oleh sistem maka akan memiliki akses ke dalam materi yang bisa diunduh sesuai yang dimaksud dengan memasukkan data mata kuliah, nama dosen dan pertemuan. Jika seorang dosen telah menambahkan sebuah tugas maka setelah mahasiswa mengisi data tadi, tugas tersebut akan muncul. 11) Dalam proses pengerjaan tugas secara kelompok, sebelumnya dosen akan membentuk kelompok secara manual yang terdiri dari satu orang ketua dan beberapa anggota kelompok. Langkah awal setelah terpilih ketua kelompok yaitu menandai ceklist ketua, jika ketua kelompok tersebut telah menandai ceklist ketua maka pilihan tersebut menjadi tidak aktif lagi. 12) Langkah berikutnya yaitu ketua kelompok bertugas untuk menambahkan anggota kelompok dengan cara memasukkan email dan NPM anggota yang dimaksud serta kode tugas yang akan dikerjakan, kemudian mengirimkan undangan tersebut. 13) Mahasiswa yang menjadi anggota kelompok akan menerima notifikasi berupa undangan yang dikirimkan oleh ketua kelompok, setelah kelompok terbentuk lengkap maka mahasiswa bisa mulai mengerjakan tugas yang diberikan oleh dosen. 14) Proses pengerjaan tugas yaitu sekelompok mahasiswa yang telah tergabung dalam satu kelompok dapat 
memilih kode tugas yang akan dikerjakan lalu mulai menjawab pertanyaan dengan memasukkan jawabannya di tempat yang telah disediakan sampai soal terakhir dalam tugas. Jika tugas telah dikerjakan sampai pada soal terakhir, mahasiswa bisa menyerahkan tugas dan tugas tersebut akan berstatus OK, namun jika tidak diserahkan maka tugas akan berstatus Belum Lengkap. 15) Setelah tugas diserahkan dan berstatus OK maka mahasiswa dapat mencetak jawaban dari tugas yang telah dikerjakan, detail masing-masing nama mahasiswa yang telah mengerjakan soal dapat dilihat dari hasil pengerjaan tugas secara berkelompok yang akan dicetak. 16) Proses selanjutnya yaitu dosen akan melakukan rekap penilaian terhadap tugas mahasiswa dengan cara memilih kelas kemudian mengunduh file yang telah diserahkan oleh masing-masing kelompok..

\section{Desain tampilan layar}

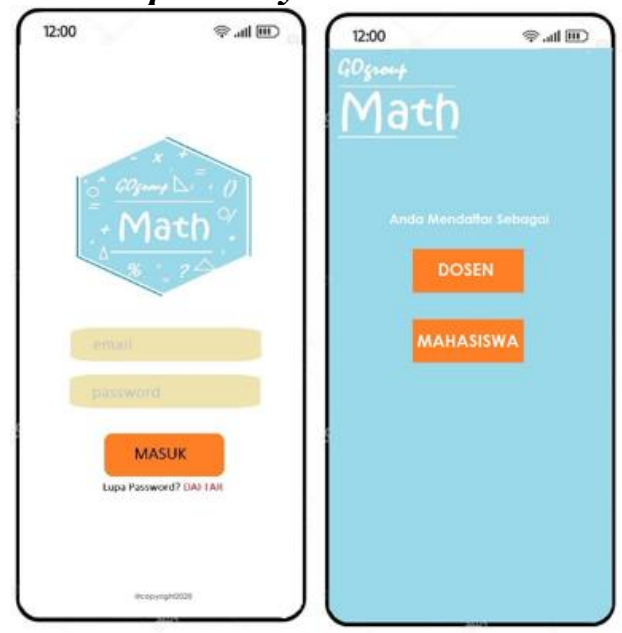

\section{Gambar 2: Tampilan Beranda dan Registrasi Go Group Match}

Pada beranda Go Group Match disajikan halaman Login bagi pengguna yang sudah terdaftar. Jika belum terdaftar, maka pengguna dapat melakukan registrasi. Layanan registrasi disediakan untu pengguna sebagai Dosen dan Mahasiswa. Keduanya memiliki hak akses yang berbeda.
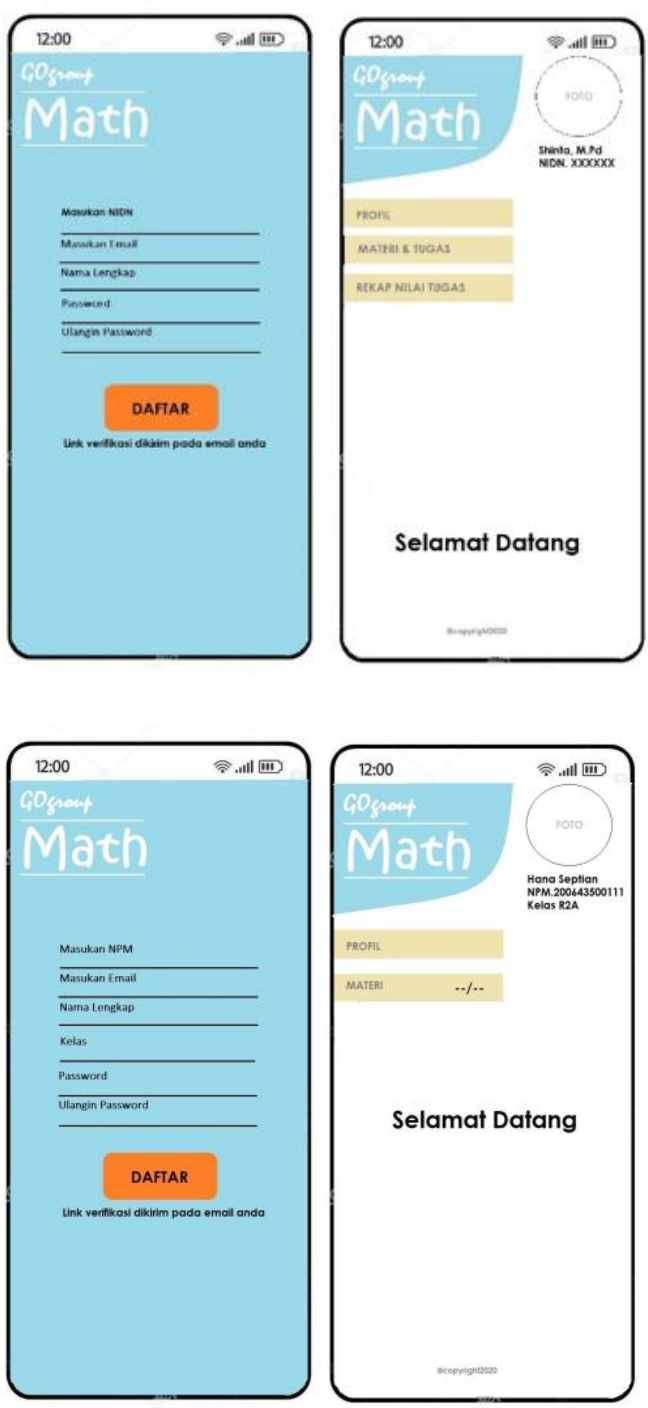

Gambar 3: Tampilan Form Registrasi dan Halaman Utama Sebagai Dosen dan Mahasiswa

Jika pengguna melakukan registrasi maka akan muncul Form Registrasi seperti pada gambar 3 dan 4 Dosen melakukan registrasi dengan Key utama yaitu NIDN yang sudah terdaftarkan pada Database sedangkan mahasiswa yaitu NPM yang dimilikinya. Jika kedua pengguna tidak memiliki NIDN dan NPM yang terdaftar maka tidak dapat melakukan registrasi pada Aplikasi Go Group Math. 

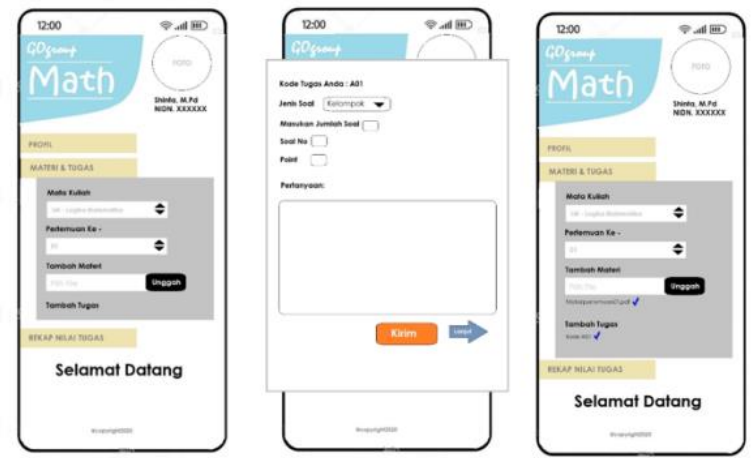

Gambar 4: Tampilan Unggah Materi dan Tugas

Setelah Dosen melakukan Login maka hal pertama yang dapat dilakukan adalah menggungah materi dan tugas yang akan dikerjakan oleh mahasiswa.

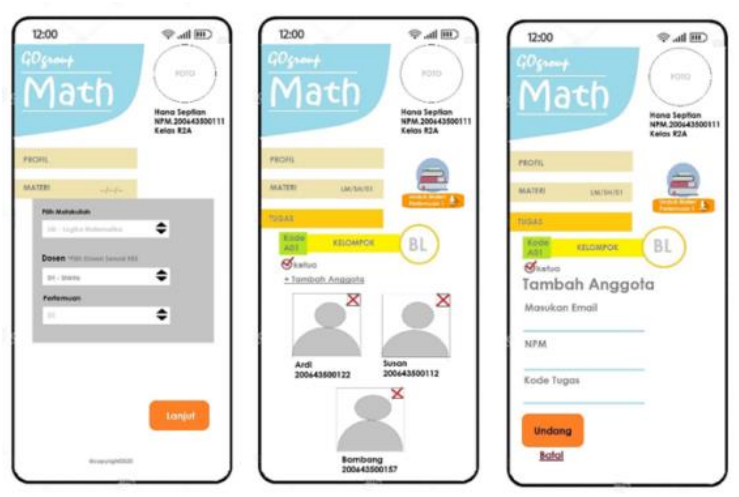

Gambar 5. Tampilan membuat kelompok sebagai Ketua

Mahasiswa setelah melakukan login maka dapaat melihat materi dengan memilih Matakuliah dan Dosen sebelumnya. Jika pada materi tersebut terdapat Tugas misalnya Tugas Kelompok, maka jika mahasiswa ingin sebagai Ketua Kelompok dapat membuat kelompok baru dengan menggundang anggota kelompok yaitu mahasiswa lainnya.
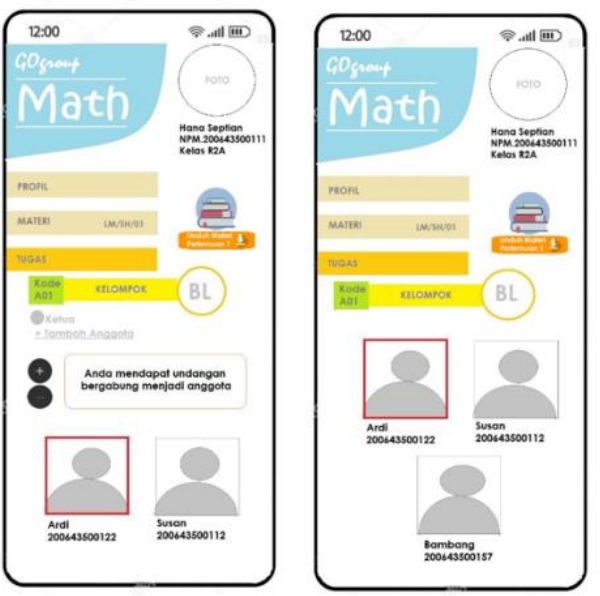

Gambar 6: Tampilan Konfirmasi Anggota Kelompok

Pada tampilan ini, mahasiswa yang diundang sebagai Anggota dari kelompok pada tugas tertentu dapat menerima undangan tersebut atau tidak jika sudah Login. Selain menerima undangan, mahasiswa dapat melihat susuan ketua dan anggota kelompok. Akan tetapi mahasiswa yang sudah memiliki undangan tidak dapat menjadikan dirinya Ketua kecuali menolak undangan tersebut dan membuat kelompok baru.
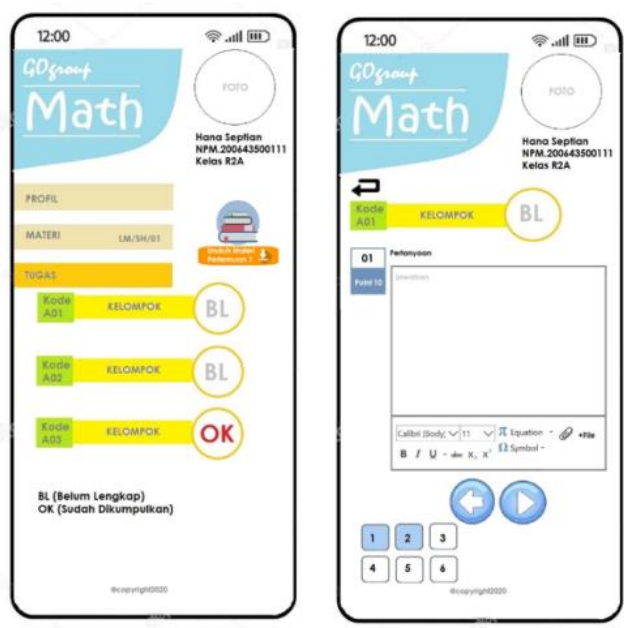

Gambar 7: Tampilan Pengerjaan Tugas 


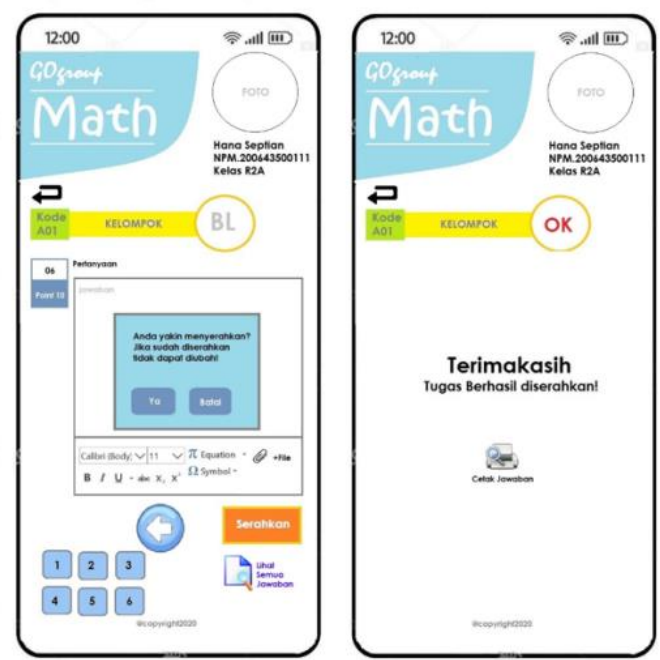

Gambar 8: Tampilan Pengumpulan Tugas

Tampilan dari pengerjaan Tugas dijelaskan pada Gambar 6, Mahasiswa mengerjakan setiap step sesuai dengan langkah yang disediakan. Contoh pada Gambar 7 adalah Soal no 4 dengan Point 10 jika benar. Setelah semua nomor dikerjakan maka mahasiswa wajib menyerahkannya (lihat Gambar 7). Ketika tugas sudah diserahkan maka akan muncul Pesan bahwa "Tugas Berhasil Diserahkan!". Maka dengan demikian, tugas yang sudah diserahkan tidak dapat diubah kembali jawabannya dan sudah terekam oleh sistem.

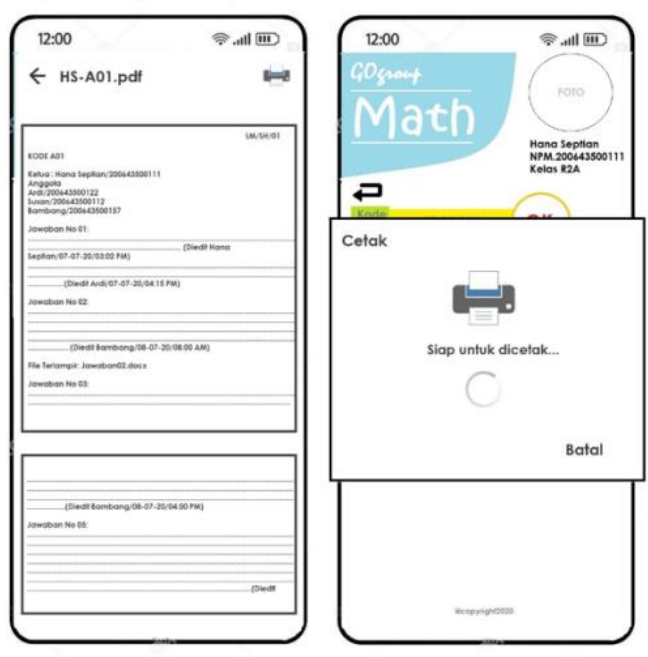

Gambar 9: Tampilan Cetak Tugas

Sebelum tugas diserahkan, mahasiswa dapat melakukan pencetakan dari tugas yang sudah dikerjakan sebagai Backup apabila terjadi kesalahan pengiriman tugas pada aplikasi Go Group Math.

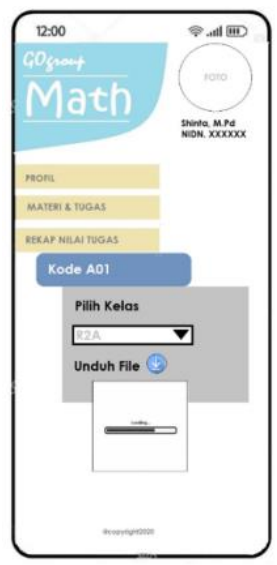

\section{Gambar 10: Tampilan Rekap Tugas}

Rekap tugas dilakukan oleh Dosen. Setelah login, dosen memilih Kode Tugas lalu kelas yang akan direkap hasil tugasnya dan menggunduh semua file tugas per kelas.

Proses belajar tidak sekedar menghafal konsep saja melainkan dapat menghubungkan konsep tersebut untuk menghasilkan pemahaman yang utuh sehingga apa yang dipelajari dapat dipahami dengan baik dan tidak mudah dilupakan [6]. Atas dasar tersebut maka diharapkan pembelajaran dengan berbagai multimedia da[ay memberikan kemudahan akses pembelajaran seperti yang kita lakukan saat pandemi covid-19. Multimedia interaktif akan mempermudah guru dalam menjalankan materi pelajaran tugasnya menyampaiakan pada dengan media siswanya, selain itu pembelajaran ini secara tidak langsung akan memperkenalkan teknologi pada siswa dan guru itu sendiri [7]. Siswa diharapkan akan mampu untuk mengenal dan menggunakan teknologi informasi dan komunikasi lebih bijak terutama dalam melakukan proses kegitan pembelajaran secara daring. Proses pembelajaran matematika memerlukan suatu alat bantu sebagai penunjang belajar tanpa harus berkutat dengan pembelajaran 
yang membosankan dikelas yang dipenuhi dengan tugas-tugas [8]. Penggunaan teknologi juga diharapkan dapan meminimalisir kebosanan yang siswa hadapi. Dalam memberikan pembelajaran matematika untuk anak-anak, diperlukan strategi yang tepat agar anak-anak sekolah dasar mampu menerima materi yang diberikan oleh guru. Melalui media aplikasi pembelajaran yang menggunakan multimedia adalah salah satu cara yang tepat untuk menyampaikan materi belajar dalam bentuk gambar, text dan audio [9]. Perangkat pembelajaran dan perangkat penilaian hasil belajar yang mumpuni tersebut tentu tidak akan mem-berikan hasil yang memuaskan jika tanpa peran serta yang baik dari guru dan siswa [10]. siswa berminat belajar matematika menggunakan media pembelajaran berbasis android [11]. Atas dasar itu maka penelitiam tentang media pembelejaran ini sangat baik untuk diterrapkan bagi siswa maupun mahasiswa terutama yang berkaitan dengan pembelajaran matematika.

\section{SIMPULAN}

Berdasarkan hasil dan pembahasan yang telah disajikan maka dapat disimpulkan bahwa rancangan aplikasi Go Group Math ini dapat dilanjuktan untuk pengembangan sistem yang akan di lakukan versi desktop dan yang nantiknya akan di gunakan versi android. Diharapkan dengan perancangan aplikasi ini dapat bermanfaat khususnya untuk dunia pendidikan. Aplikasi ini dapat diterapkan ketika sudah sampai tahap implementasi dan evaluasi untuk nantiknya akan di gunakan dalam skala besar. adapun kelanjutan dari penelitian ini adalah tahapan pengembangan, implementasi dan evaluasi.

\section{DAFTAR PUSTAKA}

[1] A. H. Nasution, "Microsoft mouse mischief: memfasilitasi pembelajaran ionteraktif, kolaburatif dan menarik tingkar sekolah dasar," J. Tek. Inform. dan Sist. Inf., vol. 1, no. 3, pp. 292-301, 2015, doi: 10.28932/jutisi.v1i3.411.

[2] S. Agung, "Pemanfaatan apliksi geogebra dalam pembelajaran matematika SMP," in Seminar Nasional, 2018, vol. 03, pp. 312322.

[3] S. N. Hikmah and S. Maskar, "Pemanfaatan aplikasi microsoft [ower point pada siswa SMP kelas VIII dalam pembelajaran koordinat kartesius," J. Ilm. Mat. Realis., vol. 1, no. 1, pp. 15-19, 2020.

[4] Nuryadi Nuryadi, "Pengembangan media matematika mobile learning berbasis android ditinjau dari kemampuan pemecahan masalah," $J$. Pendidik. Surya Edukasi, vol. 5, no. 1, pp. 1-13, 2019.

[5] R. Masykur, N. Nofrizal, and M. Syazali, "Pengembangan media pembelajaran matematika dengan micrpmedia flash," Al-Jabar J. Pendidik. Mat., vol. 8, no. 2, pp. 177-186, 2017, doi: 10.24042/ajpm.v8i2.2014.

[6] A. T. Saputro, K. Kriswandani, and N. Ratu, "Pengembnagan media pembelajaran menggunakan aplikasi construct 2 pada materi aljabar kelas VII," JTAM $\mid$ J. Teor. dan Apl. Mat., vol. 2, no. 1, pp. 1-8, 2018, doi: 10.31764/jtam.v2i1.219.

[7] A. Hartanto, "Pembelajaran matematika materi bangun ruang balok dengan aplikasi multimedia interaktif di SD Negeri Teguhan Sragen," in Seminar Riset Unggulan Nasional Informatika dan Komputer FTI UNSA 2013, 2013, vol. 2, no. 1, pp. 85-89.

[8] A. A. Nugroho, R. W. Y. Putra, F. G. Putra, and M. Syazali, "Pengembangan blog sebagai media pembelajaran matematika," Al-Jabar J. Pendidik. Mat., vol. 8, no. 2, pp. 197-203, 2017, doi: 10.24042/ajpm.v8i2.2028. 
[9] D. Waskito, "Media pembelajaran interaktif matematika bagi sekolah dasar kelas 6 berbasis multimedia," Speed - Sentra Penelit. Eng. dan Edukasi, vol. 9, no. 1, pp. 20-26, 2017.

[10] K. Kuncoro, K. Singgih, A. Suyitno, and E. Sugiharti, "Keefektifan pembelajaran TPS berbantuan mouse mischief terhadap hasil belajar siswa," Kreano J. Mat. Kreat., vol. 5, no. 2, pp. 205-211, 2014, doi: 10.15294/kreano.v5i2.4551.

[11] H. H. Batubara, "Pengembangan media pembelajaran matematika berbasis android untuk siswa $\mathrm{SD} /$ MI," MUALLIMUNA J. Madrasah Ibtidaiyah, vol. 3, no. 1, pp. 12-27, 2017. 